\title{
ASSESSMENT OF THE FACILITIES OF UNIVERSITY LIBRARY TO PROMOTE READING CULTURE AMONG THE USERS: A STUDY OF SCIENCE POSTGRADUATE STUDENTS IN KARNATAKA STATE AKKAMAHADEVI WOMEN'S UNIVERSITY, VIJAYAPURA
}

\author{
DR. SHANTADEVI. $T^{1} \&$ SHAMBHAVI ${ }^{2}$
}

${ }^{1}$ Associate professor and chairperson Department of Library and information Science, Karnataka State Akkamahadevi Women's University, Vijayapura, Karnataka, India

${ }^{2}$ Research scholar Department of library and information Science, Karnataka State Akkamahadevi Women's University Vijayapura, Karnataka, India

\begin{abstract}
This paper reveals about assessment of the facilities of University library to promote reading culture among the science postgraduate students of the Karnataka State Akkamhadevi Women's University Vijayapura. Libraries are major resource centre for developing a reading culture. The author discuss about online or offline services and facilities of the university library. This study result shows majority of the respondents are depending on the digital technologies, so libraries should provide digital facilities to promote reading culture among the science postgraduate students. KEYWORDS: Reading, Reading habit, Reading culture
\end{abstract}

Received: Dec 01, 2020; Accepted: Dec 21, 2020; Published: Jan 09, 2021; Paper Id.: IJLSRDEC20204

\section{INTRODUCTION}

Reading promotes an extensive range of knowledge to the reader. Reading is basic need for the every human beings and it gives a lot of advantages to the readers, like it improves readers communication, improves readers vocabulary, it gives wide range of ideas to the readers, it builds curiosity of the readers etc. Karnataka State Akkamahadevi women's university is one of the first women's universities in Karnataka and it offers various facilities to promote women's education.

\section{About KSAWU, Vijayapura University Library}

Karnataka State Akkamahadevi Women's University library is located at central place of the university campus. It has more than 1Lakh collections of the library and its having well qualified library staff also. Library provides various services to promote reading culture among the library users like book borrowing service, Reading room facility, reference and referral service, Newspaper service, document delivery service, ILL service, OPAC and smartcard service, reprographic service, users orientation programmes, anti-plagiarism service, internet access, download journals and e-books, INFLIBNET/IUC facilities.

\section{Need for the study}

Karnataka State Akkamahadevi Women's University aims at providing formal education to the female students who get admission. The students get their education through class room, library, lectures, seminars, conferences, workshops etc. In 
this digital era students are need to read variety of books and other related materials through online or offline/ electronic resources. Karnataka State Akkamahadevi women's University is having centrally very beautiful constructed library building with more number of resources. It provides variety of the resources like books, Newspapers, Journals, Magazines, electronic resources and well equipped reading room as well as reading environment also. To understand Students perception towards reading culture for Online and offline resources and their Searching Strategies and type of resources they consulted in library for various purposes. Libraries play a vital role in enhancing the learning experience, providing students with all the materials and services they need to improve their knowledge.Libraries need to centre of attention on students in order to satisfy their needs.

\section{REVIEW OF LITERATURE}

1. Mlay, Samali \& Sabi, Humphrey M. (2019) conducted a study entitled "A Structural analysis of ICT-based intervention on reading habits in Uganda". This article describe the information and communication technologies unlock new opportunities for pursuing culture, where people go after involved to leisure reading, in developing countries. Major results from 337 sustainable responses specify that ICT usage, home culture, school culture and expendable income significantly affect the reading habits of university students in Uganda.

2. Vijayalaxmi Hippargi (2019) conducted a study under the title "Effect of demographic factors on reading habits among youths with special reference to Dharwad district". This theses describes it is a complex interaction between text and the reader moulded by past Knowledge, experience, attitude. It requires continues practice, development fine-tuning Creativity and critical analysis.

3. Nuning Kurniasih (2017) conducted a study under the title "Reading Habits in Digital Era: Indonesian people do not like reading, is it true?" In this paper describes various surveys indicate very low per cent of reading interest in Indonesia. But now a day's Digital technologies has changed Peoples reading culture. .

4. Krishnamurthy Channapatna, Awari and Veeresh. (2015) conducted a study under the title "Newspaper Reading Habits among Post-Graduate Student of Karnataka University, Dharwad". Reading is a way to get better knowledge of one's own experiences and it can be an exciting journey to self-discovery. Reading transfers experiences to the individual so that the reader may expand one`s horizons identity. Extend and intensity his or her interest and gain deeper understanding of the world. Newspaper is also an important source of information for all and brings new of daily happening of the world.

5. Danladin Diyoshak Rhoda \& Soko Yohanna Rejoice (2018) conducted a study under the title "The Role of School libraries in Promoting Reading culture among secondary School Students: A case study of Federal Government college, JOS". This article describes that students do not have opportunities of borrowing books from the library and lack of interesting books. Major recommendations put forward by the researchers include that teacher librarians should host reading related events at school as a way to promote reading. Create attractive displays of books in the library to arouse the interest of learners; librarians should take advantage of the social media.

6. Alindele Nadia (2012) conducted a study under the title "Reading Culture, Parental Involvement and children's Development in formative Years: The covenant University Experience". This article Most of the respondents are of the opinion that learning activities provided by nursery school are not sufficient for children's development without parental involvement on the average parents spend at least one hour reading to their children, but mainly during the weekends. The 
Akkamahadevi Women's University, Vijayapura

availability of time is a majorobstacle faced by parents in cultivating reading culture for their children in cases, while lack of parental involvement account for $23.3 \%$. Only $3.3 \%$ of the respondents thought reading to children is a waste of time. Based on the results of the study appropriate recommendations were made.

7. Poosapati Durgaiah (2015) conducted a study under the title "reading habits among student teachers with respect to gender and qualification" The present study was conducted on 600 student teachers from Hyderabad and Ranga Reddy districts of Telangana State. In this study shows that there was a notable difference in reading habits with respect to gender and qualification among the student teachers.

\section{OBJECTIVES OF THE STUDY}

- Identify the reading culture among the Karnataka State Akkamahadevi women's university Science Postgraduate students.

- Identify the availability of facilities by the university library of KSWAU, Vijayapura.

- To assess the facilities provided by library to promote reading culture among the students.

- To assess the use of facilities provided by library among respondents.

\section{METHODOLOGY}

In the present Study follow the Survey Method of research. Secondary data collected through books, Journals and databases in the concerned them. To collect primary data from the target population Structured Questionnaire/ Interview method is followed. Questionnaire will be designed based on the objectives of the study identifying facet and major facets of the study. Questionnaires were distributed through offline and online mode among the Science Postgraduate students in Karnataka State Akkamahadevi Women's university, Vijayapura. The data was examined, organized and analysed as per the major objectives of the study.

\section{Sampling Design:}

The study has been conducted on Assessment of the facilities of university library to promote reading culture among Science postgraduate students. Totally 407 questionnaire were distributed through offline and online. Out of which 229 questionnaires was received from the selected sample with response rate of $56.26 \%$. For the random sampling technique was used to the sample from population.

\section{Data Analysis and Interpretation:}

Research process includes with classification of the data, tabulation of the data, analysis and interpretation of the data. Total 407 questionnaires were distributed among Science Postgraduate students Karnataka state Akkamahadevi women's university, Vijayapura, among them 229 valid responses were received from the selected population with response rate $56.26 \%$. That data has been classified, tabulated and analysed based on the major objectives of the present study and using SPSS software. Following data will be presented in the form of frequency, percentage tables and statistical tests.

Table 1:Location Wise distribution of the Respondents

\begin{tabular}{|l|l|l|r|}
\hline SI.No & \multicolumn{1}{|c|}{ Location } & Frequency & $\%$ \\
\hline 1 & Rural & 123 & $53.7 \%$ \\
\hline
\end{tabular}




\begin{tabular}{|l|l|l|l|}
\hline 2 & Urban & 84 & $36.7 \%$ \\
\hline 3 & Semi Urban & 22 & $9.6 \%$ \\
\hline & Total & $\mathbf{2 2 9}$ & $\mathbf{1 0 0 . 0} \%$ \\
\hline
\end{tabular}

Table-1 shows the respondents of the study that is Science Postgraduate Students of Karnataka State Akkamahadevi women's University, Vijayapur belongs to different locations. More than 53.7\%, (N=123) of respondents from rural area, 36.7\%, $(\mathrm{N}=84)$ from urban area, and 9.6\%, $(\mathrm{N}=22)$ from semi urban area.

Table 2: Semester wise distribution of the Respondents

\begin{tabular}{|l|l|l|l|}
\hline SI.No & Semester & Frequency & $\%$ \\
\hline 1 & IV semester & 176 & $76.9 \%$ \\
\hline 2 & IInd semester & 53 & $23.1 \%$ \\
\hline & Total & $\mathbf{2 2 9}$ & $\mathbf{1 0 0 . 0} \%$ \\
\hline
\end{tabular}

Table-2 reveals the semester wise distribution of the respondents observed that greater study population $76.9 \%$ are studying IVth semester, remaining $23.1 \%$ re from IInd semester. It can be concluded that majority of the study population are from higher semester.

Table 3: Facilities of University Library to promoteReading culture among the Respondents

\begin{tabular}{|l|l|l|l|}
\hline SI.No & $\begin{array}{c}\text { Facilities provided by the } \\
\text { University Library }\end{array}$ & Frequency & $\%$ \\
\hline 1 & Newspaper Service & 125 & $56.3 \%$ \\
\hline 2 & Internet Facility & 122 & $55.0 \%$ \\
\hline 3 & Reading room facility & 122 & $55.0 \%$ \\
\hline 4 & Reference service & 118 & $53.2 \%$ \\
\hline 5 & Book bank Facility & 114 & $51.4 \%$ \\
\hline 6 & Book Exhibition & 110 & $49.5 \%$ \\
\hline 7 & Photocopying & 101 & $45.5 \%$ \\
\hline 8 & New Arrivals & 97 & $43.7 \%$ \\
\hline 9 & Periodicals & 83 & $37.4 \%$ \\
\hline 10 & OPAC & 51 & $23.0 \%$ \\
\hline 11 & Inter library loan & 44 & $19.8 \%$ \\
\hline 12 & Remote accessing & 12 & $5.4 \%$ \\
\hline & Total & $\mathbf{1 0 9 9}$ & $\mathbf{4 9 5 . 0 \%}$ \\
\hline
\end{tabular}

Table- 8 shows number of services provided by the university library to promote reading culture to the university students. Majority of the respondents are getting benefits for improving reading habits. Majority of the respondents $56.3 \%$ are using Newspaper service, 55.0\%of the respondents using Internet Facility and Reading room facility, 53\% of the respondents are using Reference services $51.4 \%$ of the respondents are getting Book bank facilities also, more than $49.5 \%$ of the respondents are getting Book exhibition services, further $45.5 \%$ of the respondents are using Photocopying services, nearly $43.7 \%$ of the respondents are using new arrival service, $37.4 \%$ of the respondents are using periodical services, further $23.0 \%$ of the respondents are using OPAC facility for the library, $19.8 \%$ of the respondents are getting benefit for the inter library loan facility and only few member of the respondents $5.4 \%$ are getting remote accessing facilities. 
Table 4: Department wise distribution of the Respondents

\begin{tabular}{|l|l|l|l|}
\hline SI.No & \multicolumn{1}{|c|}{ Departments } & Frequency & \multicolumn{1}{c|}{$\%$} \\
\hline 1 & Mathematics & 44 & $19.2 \%$ \\
\hline 2 & Chemistry & 35 & $15.3 \%$ \\
\hline 3 & Botany & 31 & $13.5 \%$ \\
\hline 4 & Zoology & 29 & $12.7 \%$ \\
\hline 5 & Physics & 28 & $12.2 \%$ \\
\hline 6 & Food and Nutrition & 23 & $10.0 \%$ \\
\hline 7 & Computer Science & 20 & $8.7 \%$ \\
\hline 8 & Bio-informatics & 8 & $3.5 \%$ \\
\hline 9 & Statistics & 8 & $3.5 \%$ \\
\hline 10 & Computer Application & 3 & $1.3 \%$ \\
\hline & Total & $\mathbf{2 2 9}$ & $\mathbf{1 0 0 . 0} \%$ \\
\hline
\end{tabular}

Table-3 reveals department wise distribution of the respondents. More than $3.5 \%$, $(\mathrm{No}=8)$ respondents belongs to Bio-informatics department, 13.5\%, $(\mathrm{No}=31)$ respondents belongs to Botany department, 12.7\%, $(\mathrm{No}=29)$ respondents belongs to Zoology department, 19.2\%, $(\mathrm{No}=44)$ respondents belongs to Mathematics department, 3.5\%, $(\mathrm{No}=8)$ respondents belongs to Statistics departments, $12.2 \%,(\mathrm{No}=28)$ respondents belongs to Physics department, $15.3 \%$, $(\mathrm{No}=35)$ respondents belongs to Chemistry department, 8.7\%, $(\mathrm{No}=20)$ respondents belongs to Computer Science department, 1.3\%, $(\mathrm{No}=3)$ respondents belongs to Computer Applications department and 10.1\%, $(\mathrm{No}=23)$ respondents belongs to Food and Nutrition departments.

Table 5: Opinion of the respondents about theCollections of the Library

\begin{tabular}{|l|l|l|l|}
\hline SI.No & $\begin{array}{l}\text { Opinion } \\
\text { collections of the } \\
\text { library }\end{array}$ & Frequency & $\mathbf{\%}$ \\
\hline 1 & Good Collection & 130 & 56.8 \\
\hline 2 & Average Collection & 65 & 28.4 \\
\hline 3 & Poor Collection & 34 & 14.8 \\
\hline & Total & $\mathbf{2 2 9}$ & $\mathbf{1 0 0}$ \\
\hline
\end{tabular}

Above table shows that more number $56.8 \%,(\mathrm{No}=130)$ of the respondents says Library have a good number of the collection, while $28.4 \%,(\mathrm{No}=65)$ of the respondents says Library having Average number of collections and only some of the respondents $14.8 \%,(\mathrm{No}=34)$ are says library having poor collections.

Table 6: Purpose of visit to the Library

\begin{tabular}{|l|l|l|l|}
\hline SI.No & $\begin{array}{l}\text { Purpos } \\
\text { e to } \\
\text { visit the } \\
\text { library }\end{array}$ & $\begin{array}{l}\text { Freque } \\
\text { ncy }\end{array}$ & \% \\
\hline 1 & Reading & 210 & $91.7 \%$ \\
\hline 2 & $\begin{array}{l}\text { Photoco } \\
\text { pying }\end{array}$ & 73 & $31.9 \%$ \\
\hline 3 & $\begin{array}{l}\text { Consult } \\
\text { librarian }\end{array}$ & 24 & $10.5 \%$ \\
\hline 4 & $\begin{array}{l}\text { Consult } \\
\text { library } \\
\text { staff }\end{array}$ & 22 & $9.6 \%$ \\
\hline & Total & $\mathbf{3 2 9}$ & $\mathbf{1 4 3 . 7}$ \\
\hline
\end{tabular}


Table 5 shows that more than $91.7 \%(\mathrm{No}=210)$ of the respondents are going to the library for purpose of reading. $31.7 \%(\mathrm{No}=73)$ of the respondents are only the visiting of the Photocopying purpose, $10.5 \%(\mathrm{No}=24)$ of the respondent are the consult of the Librarian and $9.6 \%(\mathrm{No}=22)$ of the respondents are the Consult library staff.

Table 7: Frequency of Reading

\begin{tabular}{|l|l|l|l|}
\hline SI.No & Frequency of reading & Frequency & \multicolumn{1}{c|}{$\%$} \\
\hline 1 & Everyday & 119 & 52.0 \\
\hline 2 & Once in 2 days & 45 & 19.7 \\
\hline 3 & Once in 3 days & 19 & 8.3 \\
\hline 4 & Once in week & 17 & 7.4 \\
\hline 5 & Occasionally & 15 & 6.6 \\
\hline 6 & Only Exam time & 14 & 6.1 \\
\hline & Total & $\mathbf{2 2 9}$ & $\mathbf{1 0 0 . 0}$ \\
\hline
\end{tabular}

Further question was asked to the respondent's i.e., frequency of reading. Greater number of the respondents $52.0 \%(\mathrm{No}=119)$ are read every day, $19.7 \%(\mathrm{No}=45)$ of the respondents are read once in two days, $8.3 \%(\mathrm{No}=19)$ of the respondents are read once in three days, 7.4\% $(\mathrm{No}=17)$ of the respondents read once in a week, 6.6\% (15) of the respondents are read occasionally and $6.1 \%(\mathrm{No}=14)$ of the respondents are read only exam purpose so only exam time they read.

Table 8: How many hours do you read?

\begin{tabular}{|l|l|l|l|}
\hline SI.No & Reading Hours & Frequency & $\%$ \\
\hline 1 & one to three hours & 150 & 65.5 \\
\hline 2 & less than one hour & 56 & 24.5 \\
\hline 3 & 3 to 6 hours & 19 & 8.3 \\
\hline 4 & more than 6 hours & 4 & 1.7 \\
\hline & Total & $\mathbf{2 2 9}$ & $\mathbf{1 0 0 . 0}$ \\
\hline
\end{tabular}

Table-28 shows how many hours respondents are read in a day. Significantly more number of the respondents $65.5 \%$ is read one to three hours per day $(\mathrm{No}=150)$, every day less than one hours read $24.5 \%$ of the respondents $(\mathrm{No}=56)$, nearly $8.3 \%$ of the respondents are three to six hours read per day $(\mathrm{No}=19)$ and least number of the respondents $1.7 \%$ are read more than six hours above $(\mathrm{No}=4)$.

Table 9: Language preference of the respondents reading

\begin{tabular}{|l|l|l|l|}
\hline SI.No & \multicolumn{1}{|c|}{$\begin{array}{c}\text { Language of the } \\
\text { Respondent }\end{array}$} & Frequency & $\%$ \\
\hline 1 & English & 182 & $79.5 \%$ \\
\hline 2 & Kannada & 99 & $43.2 \%$ \\
\hline 3 & Hindi & 53 & $23.1 \%$ \\
\hline 4 & Any other & 11 & $4.8 \%$ \\
\hline & Total & $\mathbf{3 4 5}$ & $\mathbf{1 5 0 . 7 \%}$ \\
\hline
\end{tabular}

Table-29 explains preference of language to use by the respondents. It is found that Majority of the respondents $79.5 \%$ are prefer to read in English language $(\mathrm{No}=182)$, More than $43.2 \%$ of the respondents are prefer to reading in Kannada language $(\mathrm{No}=99)$, further $23.1 \%$ of the respondents are prefer to read in Hindi language $(\mathrm{No}=53)$ and some of the respondents $4.8 \%(\mathrm{No}=11)$ are like to read in some other languages like Urdu language, Marathi language etc. 
Table 10:Time of Reading

\begin{tabular}{|l|l|l|l|}
\hline SI.No & \multicolumn{1}{|c|}{ Time of Reading } & \multicolumn{1}{c|}{ Frequency } & \multicolumn{1}{c|}{$\%$} \\
\hline 1 & Morning & 115 & 50.22 \\
\hline 2 & Afternoon & 17 & 7.42 \\
\hline 3 & Evening & 44 & 19.21 \\
\hline 4 & Night & 67 & 29.26 \\
\hline 5 & At my own leisure time & 85 & 37.12 \\
\hline & Total & $\mathbf{3 2 8}$ & $\mathbf{1 4 5 . 1 \%}$ \\
\hline
\end{tabular}

Above table shows time spent for the reading among respondent. More than $50.22 \%$ of the respondents are read in the morning time $(\mathrm{No}=115)$, further $37.12 \%$ of the respondents are interested to read in at their own leisure time $(\mathrm{No}=85)$, then $29.26 \%$ of the respondents are interested in Night time reading $(\mathrm{No}=67)$, some other respondents $19.21 \%$ are interested in evening time reading $(\mathrm{No}=44)$, further $7.42 \%$ of the respondents are interested to reading in afternoon $(\mathrm{No}=17)$.

Table 11: Extent of Reading

\begin{tabular}{|l|l|l|l|}
\hline SI.No & \multicolumn{1}{|c|}{ Extent of Reading } & Frequency & \multicolumn{1}{c|}{$\%$} \\
\hline 1 & Very Frequently & 53 & 23.1 \\
\hline 2 & Frequently & 102 & 44.5 \\
\hline 3 & Often & 39 & 17.0 \\
\hline 4 & Sometime & 33 & 14.4 \\
\hline 5 & Never & 2 & .9 \\
\hline & Total & $\mathbf{2 2 9}$ & $\mathbf{1 0 0 . 0}$ \\
\hline
\end{tabular}

A question asked the respondents what extent you are reading. More than $44.5 \%$ of the respondents are frequently read the resources in the library $(\mathrm{No}=102)$, further $23.1 \%$ of the respondents are read very frequently $(\mathrm{No}=53)$, another $17.0 \%$ of the respondents are read often $(\mathrm{No}=39)$, some other $14.4 \%$ of the respondents are read some times $(\mathrm{No}=33)$, and finally $0.9 \%$ of the respondents are never read $(\mathrm{No}=2)$.

Table 12: Sources consulted in the library By the Respondents

\begin{tabular}{|l|l|l|l|}
\hline SI.No & \multicolumn{1}{|c|}{$\begin{array}{c}\text { Sources consulted by the } \\
\text { Respondents }\end{array}$} & Frequency & $\%$ \\
\hline 1 & Books & 206 & $90.4 \%$ \\
\hline 2 & Newspaper & 114 & $50.0 \%$ \\
\hline 3 & Journals & 52 & $22.8 \%$ \\
\hline 4 & Magazines & 100 & $43.9 \%$ \\
\hline 5 & Online Sources & 50 & $21.9 \%$ \\
\hline 6 & Reference Sources & 106 & $46.5 \%$ \\
\hline & Total & $\mathbf{6 2 8}$ & $\mathbf{2 7 5 . 4 \%}$ \\
\hline
\end{tabular}

Karnataka State Akkamahadevi women's University library provides very good collection like books, Newspaper, Magazines, Journals, Reference books etc. Highest numbers of the respondents,i.e. 90.4\% visit the library for Book reading purpose, Smallest unit of the respondents $21.9 \%$ are visiting library for Online reading purpose, $50.0 \%$ of the respondents are Reading the newspaper for the library, $46.5 \%$ of the respondents are Reference book readers, $43.9 \%$ of the respondents are Magazine readers and $22.8 \%$ of the respondents are Journal readers. 
Table 13: Extent of use of following resources

\begin{tabular}{|l|l|l|l|l|l|l|l|l|l|}
\hline $\begin{array}{c}\text { SI.N } \\
\text { O }\end{array}$ & Sources & $\begin{array}{c}\text { Greater } \\
\text { Extent }\end{array}$ & $\begin{array}{c}\text { Good } \\
\text { Extent }\end{array}$ & \multicolumn{1}{c|}{$\begin{array}{c}\text { Some } \\
\text { Extent }\end{array}$} & Neutral & No Extent & & & \\
\hline 1 & Books & 68 & 110 & 35 & 14 & 2 & & & \\
& & 29.69432 & 48.03493 & 15.28384 & 6.113537 & 0.873362 & 915 & 3.99 & 1 \\
\hline 2 & Newspaper & 66 & 106 & 39 & 15 & 3 & & & \\
& & 28.82096 & 46.28821 & 17.03057 & 6.550218 & 1.310044 & 904 & 3.947598 & 2 \\
\hline 3 & Journals & 42 & 78 & 63 & & 19 & & & \\
& & 17.90393 & 34.06114 & 27.51092 & 2711.79039 & 8.296943 & 784 & 3.423581 & 4 \\
\hline 4 & Magazines & 51 & 95 & 39 & 28 & 16 & & & \\
& & 22.27074 & 41.48472 & 17.03057 & 12.22707 & 6.9869 & 824 & 3.598253 & 3 \\
\hline 5 & E-Journals & 26 & 81 & 60 & 29 & 33 & & & \\
& & 11.35371 & 35.37118 & 26.20087 & 12.66376 & 14.41048 & 725 & 3.165939 & 6 \\
\hline 6 & E-Books & 24 & 83 & 52 & 27 & 43 & & & \\
& & 10.48035 & 36.24454 & 22.70742 & 11.79039 & 18.77729 & 705 & 3.078603 & 7 \\
\hline 7 & Online & 32 & 83 & 51 & 24 & 39 & & & \\
& Databases & 13.9738 & 36.24454 & 22.27074 & 10.48035 & 17.03057 & 732 & 3.196507 & 5 \\
\hline
\end{tabular}

Another question asked to the respondents what extent you are using library resources.Above table-7 denotes analysis of given answers. Highest numbers of the respondents i.e.48.03493\% $(\mathrm{No}=110)$ are using books in greater extent and only few number of the respondents $6.113537 \%(\mathrm{No}=14)$ are using books in small extent, more number of the respondents $46.28821 \%(\mathrm{No}=106)$ are using Newspaper in Good extent and only few numbers of the respondents $6.550218 \%(\mathrm{No}=15)$ are using Newspaper in small extent, nearly $34.06114 \%(\mathrm{No}=78)$ of the respondents are using Journals in good extent and $11.79039 \%(\mathrm{No}=27)$ of the respondents are using Journal in small extent, highest number of the respondents $41.48472 \%(\mathrm{No}=95)$ are using Magazines in good extent and only $12.22707 \%(\mathrm{No}=28)$ of the respondents are using Magazines in small extent, 35.37118\% $(\mathrm{No}=81)$ of the respondents are using E-journals in good extent and only $12.66376 \%(\mathrm{No}=29)$ of the respondents are using small extent of e-journals, $36.24454 \%(\mathrm{No}=83)$ of the respondents are using E-books in good extent and only $11.79039 \%(\mathrm{No}=27)$ of the respondents are using E-books in small extent, more than $36.24454 \%(\mathrm{No}=83)$ of the respondents are using online databases in good extent and only $10.48035 \%(\mathrm{No}=24)$ of the respondents are using online databases in small extent.

Table 14: Problems faced in accessing library facilitiesIn promote reading culture of the Respondents

\begin{tabular}{|l|l|l|l|}
\hline SI.No & $\begin{array}{c}\text { Problem faced in accessing } \\
\text { library services in promoting } \\
\text { reading culture of the } \\
\text { respondents }\end{array}$ & Frequency & \% \\
\hline 1 & $\begin{array}{l}\text { Lack of Digital Facilities } \\
\text { Lack of availability of } \\
\text { resources }\end{array}$ & 100 & 43.66812 \\
\hline 2 & Lack of types of resources & 72 & 31.87773 \\
\hline 3 & Lack of training programmes & 70 & 31.44105 \\
\hline 4 & Insufficient user Education & 70 & 30.56769 \\
\hline 5 & $\begin{array}{l}\text { Lack of Knowledge on how to } \\
\text { use information retrieval skill }\end{array}$ & 69 & 30.56769 \\
\hline 6 & \multicolumn{2}{|l}{} \\
\hline
\end{tabular}




\begin{tabular}{|l|l|l|l|}
\hline 7 & Lack of Computer Knowledge & 68 & 29.69432 \\
\hline 8 & Lack of Mobile Knowledge & 67 & 29.25764 \\
\hline 9 & Lack of Human resources & 53 & 23.1441 \\
\hline & & $\mathbf{6 4 2}$ & $\mathbf{2 8 0 . 3 4 9 3 4}$ \\
\hline
\end{tabular}

Above table shows Karnataka state Akkamahadevi women's university students' problem faced with the accessing of library resources. More number of $43.66812 \%(\mathrm{No}=100)$ respondents are problem faced with the availability of lack of digital facilities like Smartphone's, Laptops, Computer systems, Wi-Fi connectivity etc., $31.87773 \%$ (No=73) are faced with the lack of resources availability, $31.44105 \%(\mathrm{No}=72)$ are faced lack of types of resources, $30.56769 \%$ $(\mathrm{No}=70)$ of the respondents are problem faced with the Insufficient user education and lack of training programmes for the accessing of library resources, 30.131\% ( $\mathrm{No}=69)$ of the respondents are faced lack of proper knowledge on how to use information retrieval skill, 29.69432\% $(\mathrm{No}=68)$ and $29.25764 \%(\mathrm{No}=67)$ of the respondents are problem faced with the lack of Computer knowledge and mobile knowledge like anywhere, any time and any one can access any resources so respondents are more depending upon the mobile phones, another $23.1441 \%(\mathrm{No}=53)$ of the respondents are problem faced with the lack of availability of Human resources.

\section{FINDINGS}

- In this study Karnataka State Akkamahadevi women's university, Vijayapura, larger number of Science Postgraduate students are from rural area.

- Majority of the respondents $76.9 \%$ from IVth semester and $23.1 \%$ of the respondents are studying IInd semester students.

- In the random sampling found that more number of science postgraduate students belongs to math and chemistry department and further very les number of the respondents from the Computer scienceand Statistics.

- Karnataka State Akkamahadevi women's university Library having good number of collection.

- Findings shows highest numbers of the respondents visit the library for reading purpose.

- Highernumber of respondents are consulting the library for Books and Newspaper reading.

- Highest numbers of the respondents weregreater extent to use books, Newspapers, Journals, Magazines, ejournals, e-books, and online databases in the library.

- Science postgraduate students give positive opinion about Number of facilities provided by the university library to promote reading culture among the university library users like well-equipped library building, reading room facility, Newspaper service, internet facilities, book exhibition, book bank facility, reference services, periodical, photo copying facilities, inter library loan, OPAC, New arrivals etc.

- Science postgraduate students of the university faced lot of problems with the accessing of library resources because of lack of digital facilities available in this internet era. 
- Highest numbers of the respondents $(52.0 \% \mathrm{No}=119)$ are read every day and least number of the respondents $6.1 \%$, No14) are only exam time reader.

- $\quad$ Majority of the respondents are every day spent one to three hours for reading.

- $\quad$ Under this study more number of the respondents are prefer in English language for reading.

- $\quad$ Significant numbers of the respondents are like read in morning time so libraries should open in morning time.

- $\quad$ Moderate number of the respondents $44.5 \%(\mathrm{No}=102)$ are frequently read.

- More number of the respondents are problem faced with the digital technologies.

\section{SUGGESTIONS}

- Library should encourage the students for reading books, Newspapers, Magazines, Journals and other materials online/offline by providing required facilities and services

- Libraries should conduct the user orientation programmes.

- $\quad$ Libraries should conduct workshops to Postgraduate students.

- Libraries should conduct awareness programmes about importance of reading habit and facilities available in the library and bring out the library facilities broacher and send all departments.

- Library should update the new technologies like barcode system, RFID technology etc.

- $\quad$ Teachers should motivate the students to use library and improve their knowledge.

- $\quad$ Parents should support the ability in promote their children's reading habits.

- Library and concerned PG departments should encourage students to get reading culture.

- To provide remote accessing technology to promote reading habits of the students.

- Remote access and internet facilities to promote library to the Science postgraduate students.

\section{CONCLUSIONS}

Reading is one of the knowledge from various resources, sharing and communicating the ideas in the form of information. Reading is a very useful gateway for gathering specific information about particular problem. In this study assess the Karnataka State Akkamahadevi Women's university library system and services to promote reading culture among the Science postgraduate students. Library provides various services to the students for develop reading habit.

\section{REFERENCES}

1. Hipparagi Vijayalaxmi, (2019). Effect of Demographic factors on Reading habits among youth: With special reference to Darwad districts. https://shodhganga.inflibnet.ac.in/handle/10603/263163

2. Mlay, Samali \& Sabi, Humphrey. (2019). A structural analysis of ICT-based intervention on reading habits in Uganda. The Information society. 1-10. https://doi.org.10.1080/01972243.2018.1542645.

3. GURAMWAR, UMESH W., and M. GHOSAL. "READING CULTURAL TRAITS IN MANJU KAPUR'S NOVEL, "THE IMMIGRANT", "International Journal of Linguistics and Literature (IJLL) ISSN(P): 2319-3956; ISSN(E): 2319-3964 Vol. 6, 
Issue 2, Feb - Mar 2017; 1-6

4. Krishna, K.M. and Adwani Neeta. (2010). Digital information and it impact on reading habit of users. SRELS journal of information management, 47(3). http://www.informaticsjournals.com

5. Kurniasih, Nuning. (2017). Reading Habit in Digital Era: Indonesian People do not Like Reading, is it true?https://doi.org.10.31227/osf.io/5apkf.

6. SAIKIA, LOTIKA. "MIRRORING THE SOCIO-CULTURAL ETHOS OF ASSAMESE LIFE: A CRITICAL READING WITH SPECIAL REFERENCE TO ASSAMESE MARRIAGE SONGS." International Journal of English and Literature (IJEL) 9.4, Aug 2019, 19-24

7. Hymavathi B. \& Surendra Babu K. (2018). Impact of information and communication Technology (ICT) on Reading Habits of Postgraduate Students in Universities Located in Chittoor District: A study.

8. Sivakumar, N., and N. Tamilselvan. "Newspaper Reading Habits of College students: A case study of Kalaignar Karunanidhi Institute of Technology." International Journal of Library science and Research 5.2 (2015): 31-36.

9. Danladin Diyoshak Rhoda \& Soko Yohanna Rejoice. (2018). The Role of School libraries in Promoting Reading culture among secondary School Students: A case study of Federal Government college, JOS. Library philosophy and practice, https://digitalcommons.unl.edu

10. Poosapati Durgaiah. (2015). Reading habits among student teachers with respect to gender and qualification. International journal for educational research studies.

11. Van der Weel, Adriaan. (2016). Monographs in a Changing Reading Culture. Against the Grain 28(3). https://doi.org.10.7771/2380-176X.7359

12. Qamar, Sadia, and Rana Kashif Shakeel. "Representation of Afghan Institution of Marriage in Khaled Hosseini's And The Mountains Echoed And A Thousand Splendid Suns: A Cultural Study." International Journal of English and Literature (IJEL) 5 (2015): 1 .

13. Veerabasaviah $M \&$ Shivappa C.R. (2018). Reading Habits among users of Vijayanagar public library in Bangalore city: A case study. International journal of information movement, 2(X), 71-75 http://www.ijim.in 

